\title{
Some epidemiological features of BCoVs infection in Al- Qadisiya province by using real time-qPCR technique.
}

\author{
Khetam Qaid Mayee Mohsen Abid Nema Alrodhan \\ Coll. of Vet. Med./ Univ. of Al-Qadisiya \\ email: dr_khokha_86@yahoo.com
}

(Received 30 September 2013, Accepted 31 October 2013)

\begin{abstract}
This study was carried out to evaluate some epidemiological features of Bovine Coronavirus infection by using one-step real-time fluorogenic quantitative reverse transcription polymerase chain reaction (RT-qPCR) assay based on SYBR Green I dye in detection. Coronaviruses detected by the same neocleocapsid $(\mathrm{N})$ gene primers under $98 \%$ similarity with HECV-4408 (human enteric Coronavirus) in children according to NCBI with product size 124bp. 285 fecal samples has been examined by routine methods against pathogenic bacteria in the intestines (E.coli, Salmonella Spp.) and Cryptosporidium parvum, the samples positive for the parasite submitted to molecular testing because they may be mixed with coronavirus infections. 100 samples were screened for the presence of $\mathrm{BCoVs}$ antigens by using a immunochromatographic rapid test as a field fast test. Where $44 \%$ of samples showed positivity to BCoVs, out of 50 samples submitted to quantitative reverse transcription (RTqPCR) assay. Out of $50-31$ samples had been positive. We found, that distribution of $\mathrm{BCoVs}$ was significantly higher in rural areas $33.3 \%-87.5 \%$ as compare to cities $71.4 \%-75 \%$, the infection in males reach to $75 \%$ vas $53.5 \%$ in females, high infection rate $62.9 \%$ in $<1-4$ months age as compare with $>1$ month age $62.9 \%$. The results of infection rate showed high percentage during February $77.7 \%$ while the percentage on (January, December, March, and April) was $(66.6 \%, 66.1 \%, 54.5 \%$ and $50 \%)$ respectively.

Key words : Bovine coronavirus, epidemiological features of $\mathrm{BCoV}$, real time-qPCR based on SYBR Green I dye, HECV-4408, BCoVs immunochromatographic rapid test.

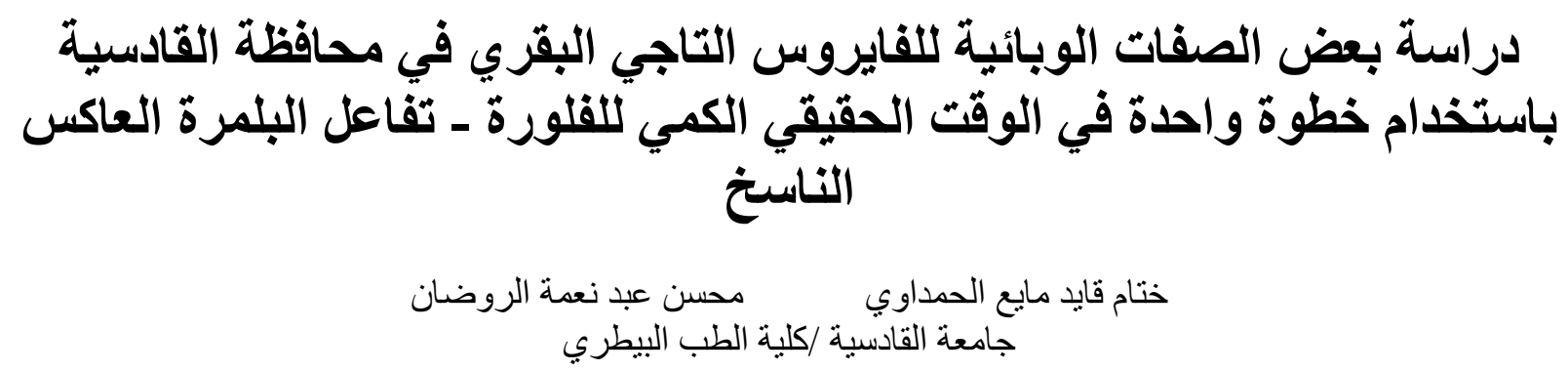

الخلاصة

أجريت هذه الدراسة لتقييم بعض السمات الوبائية لعدوى الفايروس التاجي باستخدام خطوة واحدة في الوقت الحقيقي

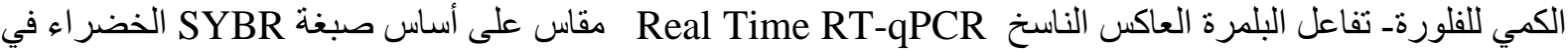

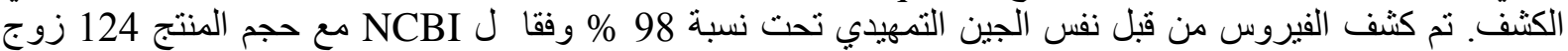

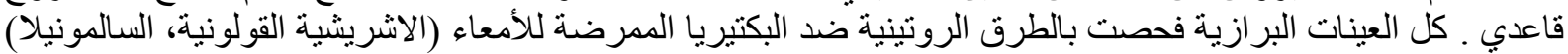
و الابو اغ الخبيئة، وقد تم استبعاد العينات الموجبة للنمو البكتيري في حين أن العينات إلينات إلموجبة للطفيلي قدمت إلى اللى الاختبار

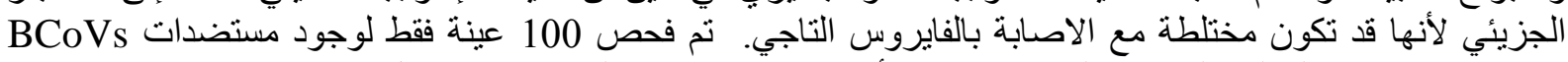

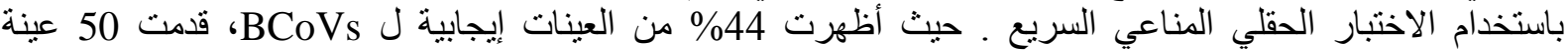

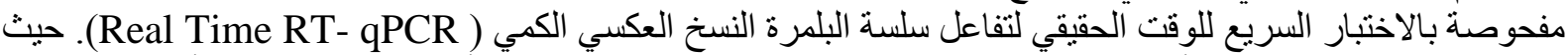

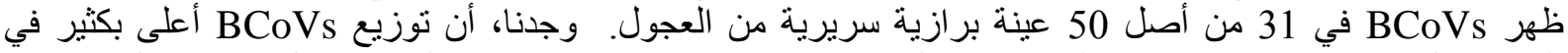

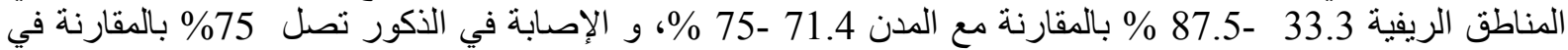
الإناث 53.5 \%. وزيادة الإصابة مع تقدم العمر > 1-4 62.9\% مع النفاض طفيف في عمر > 1 \% شهر 62.9 \% \% ؛ 


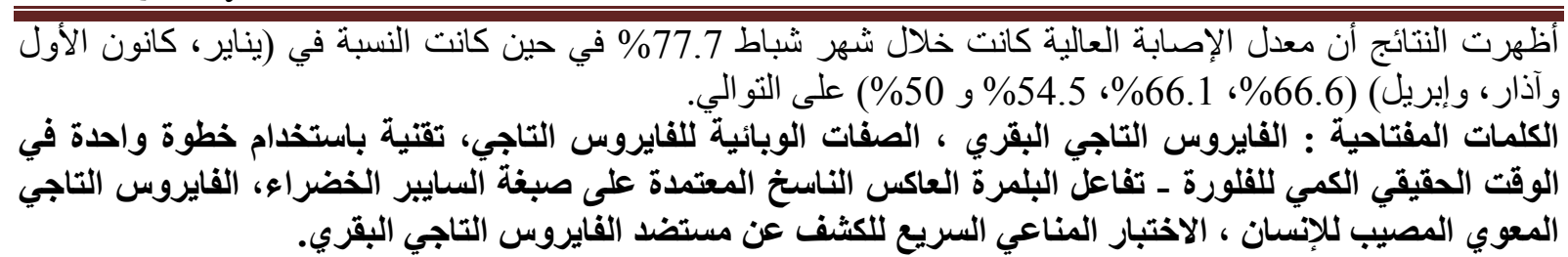

\section{Introduction}

Coronaviruses are species in the genera of animal viruses that are members of subfamily Coronavirinae in the family Coronaviridae (1). They are enveloped viruses with a positive-sense single-stranded RNA genome and chiefly infect the upper respiratory and gastrointestinal tract of mammals and birds (1)._And have an established potential for cross-species transmission that became broadly recognized with the emergence of a novel human coronavirus. Before the 2002 2003 severe acute respiratory syndrome (SARS) epidemic, coronaviruses have always been of considerable importance in animal health, they are infect a variety of livestock, poultry, and companion animals, in which they can cause serious and often fatal respiratory, enteric, cardiovascular, and neurologic diseases (2). Diarrhea among neonatal calves is a common disease. The form of the disease varies from calf to calf, some suffering acute dehydration and death whilst others suffer from sub-acute forms with malnutrition that lasts for several days (3). And the cost for the unwanted death of a calf was calculated to roughly \$ 60 UD and a reduction in mortality in farms in Kuwait was seen to have a big positive impact on the gross margins (4).

\section{Materials and methods}

History of 285 fecal samples which was freshly collected from veterinary teaching hospital and dispensaries in districts and counties of Al-Qadissyia province between December 2012 to May 2013. All fecal specimens has been exanimate within $24 \mathrm{~h}$ by routine methods against enteropathogenic bacteria ( E. coli, Salmonella Spp.) and Cryptosporidium Spp. infection, the positive bacterial growth samples has been excluded while the positive Cryptosporidium samples submitted to molecular test as possible mix infection with Coronavirus.

FASTest ${ }^{\circledR}$ BCV Strip : out of 285 samples 100 samples has been examined by rapid immunochromatographic test, the test membrane contains two unique monoclonal antibodies. One of these monoclonal antibodies is bounded to colloidal gold particles, the second is immobilized in the test zone of the strip. If the stool sample extract contains bovine Coronavirus antigen these will form an antigen-antibody complex with the gold particles. 44 positive diarrheic samples matched with 6 negative bovine coronavirus samples and converted into confirmative molecular detection.

Molecular detection : RNA extraction Viral RNA was extracted from 50 samples by using AccuZol ${ }^{\mathrm{TM}}$ Total RNA extraction kit (Bioneer, Korea) and done according to company instructions.

cDNA synthesis : Total RNA that extracted from 50 stool samples were used in cDNA synthesis step by using AccuPower ${ }^{\circledR}$ RocktScript RT PreMix kit that provided from Bioneer Company, Korea and done according to company instructions. Then Real-Time PCR was performed for detection of bovine Coronavirus by using the primers specific for Neucleocapsidgene(N) BCoVs. Forward:

(ATTTGCAGAGgGACAAGGTG) \& Reverse:

(TAGCAATTGACGCTGGTTGC) with 124bp product size. Real-Time PCR master mix was prepared by Real-Time-qPCR detection kit (AccuPower ${ }^{\circledR}$ GreenStar $^{\mathrm{TM}}$ qPCRPreMix, Bioneer. Korea), and done according to company instructions. Real time-qPCR data analysis was performed by calculation the threshold cycle number (CT value) that presented the positive 
amplification of Nucleocapsid gene in Realtime cycle number.

Statistical analysis : the results submitted to statistical study for the calculation of infection rate \& significant differences $(p<$ $0.05)$ among regions, sex, age, and months of year were studied to categorical variable by using Chi - square calculation method according to (5).

\section{Results}

By using immunocromatographic rapid test $44 \%$ out of 100 screened samples showed positivity to $\mathrm{BCoVs}$ antigen, whereas by using the molecular method as expressed in real time reverse transcription RT-qPCR cycle stages in the figures $(1,2,3, \& 4)$, the current study showed that the distribution of BCoVs was significantly higher in rural areas $87.5 \%$ as compare with cities $71.4-75 \%$. $\mathrm{BCoVs}$ infections were showed clear disparity between districts were the positivity percentage reached to $75 \%$, was no significant differences in this results, In subdistrictes, there was significant differences, the positivity percentage was $87.5 \%$. Table (1).

Table (1): Results of RT_ qPCR of BCoVs infection rate according to study regions.

\begin{tabular}{|c|c|c|c|}
\hline $\begin{array}{c}\text { Districts/sub } \\
\text { districts }\end{array}$ & $\begin{array}{c}\text { No. of } \\
\text { diarrheic } \\
\text { samples }\end{array}$ & $\begin{array}{c}\text { No. of } \\
\text { positive } \\
\text { samples }\end{array}$ & $\begin{array}{c}\text { Positivity } \\
\text { Percentage }\end{array}$ \\
\hline City center & 2 & - & $0 \% \mathrm{a}$ \\
\hline Hamza & 4 & 3 & $75 \% \mathrm{~b}$ \\
\hline Afak & 7 & 5 & $71.4 \% \mathrm{~b}$ \\
\hline Shamyia & 2 & - & $0 \% \mathrm{a}$ \\
\hline Mehanawia & 4 & 3 & $75 \% \mathrm{~b}$ \\
\hline Shafeyia & 4 & - & $0 \% \mathrm{a}$ \\
\hline Albdeer & 8 & 7 & $87.5 \% \mathrm{~b}$ \\
\hline Nuffer & 3 & 2 & $66.6 \% \mathrm{~b}$ \\
\hline Salahyia & 3 & 1 & $33.3 \% \mathrm{c}$ \\
\hline Daghara & 3 & 2 & $66.6 \% \mathrm{~b}$ \\
\hline Sumer & 10 & 8 & $80 \% \mathrm{~b}$ \\
\hline Total & 50 & 31 & $62 \%$ \\
\hline
\end{tabular}

Similar letters refers to the non-significant differences among cities while different letters refers to significant differences at $(\mathbf{p}<0.05)$.

BCoVs infection according to sex appeared no significant differences between male and females even the high rate indicated in males were $75 \%$ and in females $53.3 \%$. Table (2).

Table(2) : Results of RT_qPCR of BCoVs rate infection according to sex.

\begin{tabular}{|c|c|c|c|}
\hline Sex & $\begin{array}{c}\text { No .of } \\
\text { diarrheic } \\
\text { samples }\end{array}$ & $\begin{array}{c}\text { No. of } \\
\text { positive } \\
\text { samples }\end{array}$ & $\begin{array}{c}\text { Positivity } \\
\text { Percentage }\end{array}$ \\
\hline Male & 20 & 15 & $75 \%$ a \\
\hline Female & 30 & 16 & $53.3 \%$ a \\
\hline Total & 50 & 31 & $62 \%$ \\
\hline
\end{tabular}

Similar letters refers to the non-significant differences between sex while different letters refers to significant differences at $(\mathbf{p}<0.05)$.

The infection increased with age $<1-4$ months age $62.9 \%$ and a slight decline in $>1$ month age $62.9 \%$. There were no significant difference founded in calves during the first month of age, while the calves at $<1 \_4$ months were more susceptible to infection with BCoVs. Table (3). During February the peak of $\mathrm{BCoVs}$ reach to $77.7 \%$ in comparing with January $66.6 \%$, December $66.1 \%$, March 54.5\% and April 50\%. A months infection pattern in this study showed a significant differences between winter and spring season. Table (4).

Table (3): Results of RT_qPCR of BCoVs infection rate according to ages groups.

\begin{tabular}{|c|c|c|c|}
\hline Ages groups & $\begin{array}{c}\text { No. of } \\
\text { diarrheic } \\
\text { samples }\end{array}$ & $\begin{array}{c}\text { No. of } \\
\text { positive } \\
\text { samples }\end{array}$ & $\begin{array}{c}\text { Positivity } \\
\text { Percentage }\end{array}$ \\
\hline 1day_1months & 23 & 14 & $60.8 \%$ a \\
\hline$<1$ 4 months & 27 & 17 & $62.9 \%$ a \\
\hline Total & 50 & 31 & $62 \%$ \\
\hline
\end{tabular}

Similar letters refers to the non-significant differences between ages while different letters refers to significant differences at $(p<0.05)$

Table (4): Results of RT_qPCR of BCoVs infection rate according to months of years.

\begin{tabular}{|c|c|c|c|}
\hline Months & $\begin{array}{c}\text { No .of } \\
\text { diarrheic } \\
\text { samples }\end{array}$ & $\begin{array}{c}\text { No. of } \\
\text { positive } \\
\text { samples }\end{array}$ & $\begin{array}{c}\text { Positivity } \\
\text { Percentage }\end{array}$ \\
\hline December & 6 & 4 & $66.1 \% \mathrm{ab}$ \\
\hline January & 12 & 8 & $66.6 \% \mathrm{ab}$ \\
\hline February & 9 & 7 & $77.7 \% \mathrm{~b}$ \\
\hline March & 11 & 6 & $54.5 \% \mathrm{a}$ \\
\hline April & 12 & 6 & $50 \% \mathrm{a}$ \\
\hline Total & 50 & 31 & $62 \%$ \\
\hline
\end{tabular}

Similar letters refers to the non-significant differences among months while different letters refers to significant differences at $(\mathbf{p}<0.05)$. 
Collection of figures showing the reverse transcription RT-qPCR cycle stages: The figures (1,2,3, and 4) expressed the amplification plots represent 8 positive

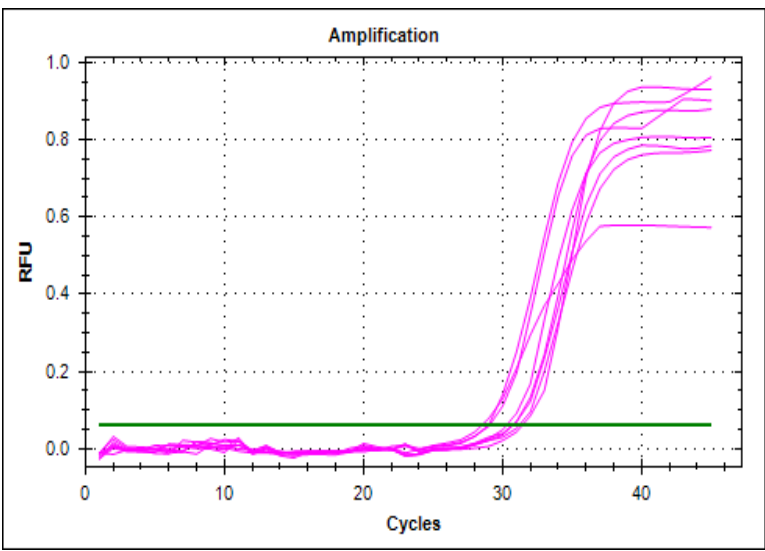

Fig. (1): Reverse Transcription Real-Time PCR amplification plot shown the positive results of Bovine enteric Coronavirus in bovine samples

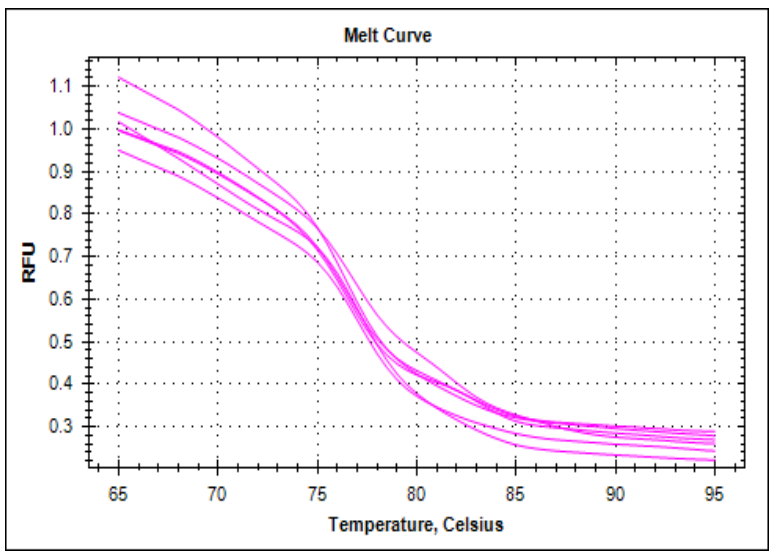

Fig. (3): Reverse Transcription Real-Time PCR melt curve shown the positive results of Bovine enteric coronavirus in bovine samples.

\section{Discussion}

immunocromatographic rapid test results which showed $44 \%$ out of 100 screened samples of positivity to BCoVs antigen. This results less than (6) Who confirmed that rapid tests for the detection of showed a high specificity $96.4 \%$, but a relatively low sensitivity $60.0 \%$ (6) this may be related to the most clinical samples collected from subclinical or chronic infected calves. Rapid test has the advantage of not requiring special samples, the results showed different positive reaction cycles of threshold $(\mathrm{Ct})$, they started reactions at 28, 29, and 30 respectively.

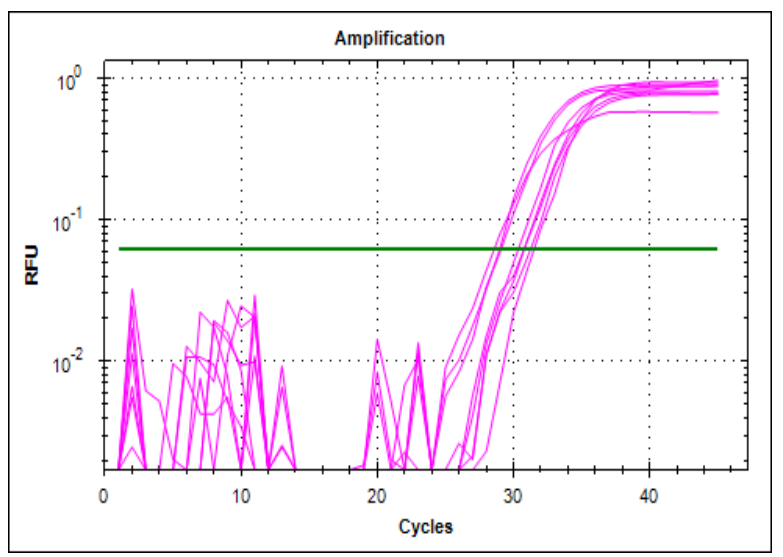

Fig. (2): Reverse Transcription Real-Time PCR amplification log plot shown the positive results of Bovine enteric coronvirus in bovine samples.

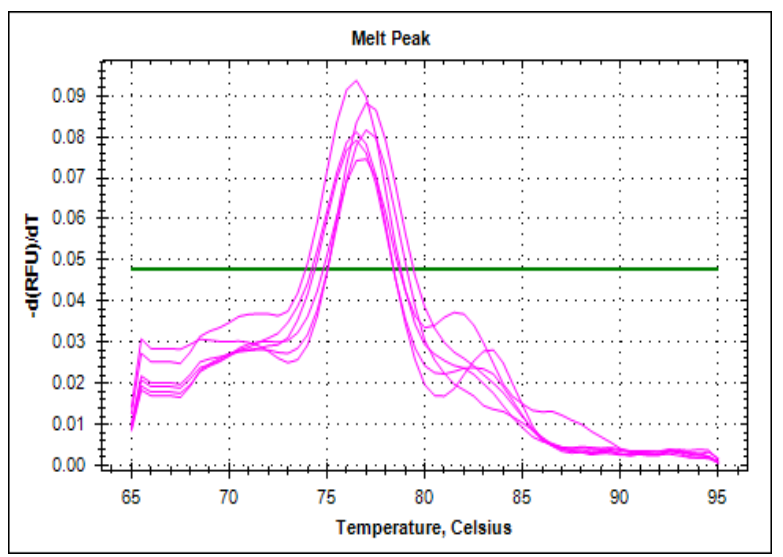

Fig. (4): Reverse Transcription Real-Time PCR melt peak shown the positive results of Bovine enteric coronavirus in bovine samples.

equipment or expertise, therefore, it is suitable for small laboratories and field research (6). whereas by using the molecular method, the current study showed that the distribution of $\mathrm{BCoVs}$ was significantly higher in rural areas in comparing with cities, the presented data give insight into the infection rate of $\mathrm{BCoVs}$ disagreements with (7) who proved that percentage in AlQadisiya province of $\mathrm{BCoVs}$ infections were 
higher than the other province Babylon, Wassit, and Najaf and showed there was no significant difference at $p \geq 0.05$ in percentage of infection with $\mathrm{BCoVs}$ in those governorates and this related to using RTPCR in detection. Because of the real-time PCR technique which was established in this study has been catalyzed wider acceptance of PCR because it is more rapid, sensitive and reproducible, while the risk of carry over contamination is minimized (8). BCoVs infections were showed clear disparity between districts, but the absent of virus in cities may due to less contact with the livestock in urban centers, small number of villages in the city, and raised of livestock flock. In subdistrictes, there was significant differences, this may be related to the geographical nature of the regions make it far from the veterinary services. Calves graze on crops in areas lacking agriculture suffers low level of food, thus be prone to skinny and susceptible to the risk of all diarrheic causes easily, and the movements of cattle population between different regions could be good reason to virus spreading. BCoVs infection according to sex appeared no significant differences between male and females even the high rate indicated in males. In fact, in the case of viral infection in general, this difference in susceptibility between males and females were shown for different viruses(9). For many years the concept of sex-based (or gender based) differences in host response to infection has been studied and appears to be highly related to differences in immunological capacities between males and females (10). Furthermore, it appears now that even though the relative importance of different factors may vary with the type of infection, X-linked genes, hormones, immunity and, at least in humans, societal context are among the factors that explain this sex-based difference $(9,10)$. Even though it remains difficult to clarify evidence on how the different factors make a difference between genders, studies aimed to addressing the question appear to more and more link specific hormones such as androgens in males and estrogens in females $(9,11)$, host innate immunity (expression of cytokines and of pattern recognition receptors such as toll-like receptors (TLR) $(12,13)$ as well as acquired immunity involving $\mathrm{T}$ and B lymphocytes (9) to explains. The infection increased with age $<1-4$ months age and a slight decline in $>1$ month age, there were no significant difference founded in calves during the first month of age, while the calves at < 1_4 months were more susceptible to infection with $\mathrm{BCoVs}$, and this may also due to the pathogen causing diarrhea in calves at an age when they have immature immune status, lacks specific antibodies illustrate high metabolism with added stresses imposed by weaning and sometimes deprivation of immune colostrum feeding (14). The results were agreement with (15) who exposed that $\mathrm{BCoV}$ is associated with enteric disease in cattle of all ages. The increase in the prevalence of coronavirus with age could be due to the fact that, as animals grow older, they were more likely to be exposed to the virus, as well more likely to come into contact with other animals that have recovered from the disease but remain as carriers. A months infection pattern in this study showed a significant differences between winter and spring season, and this results agreed with $(15,16)$ were proved the winter season in which the prevalence of calf diarrhea caused by Coronavirus is higher than other seasons because $\mathrm{BCoV}$ is moderately sensitive to heat $(17,16)$, and in spring season the results were agreement with previous reports of enteric disease caused by BCoVs in higher tropical temperatures (18), (17) who expressed another factor were alteration of the biological properties of the $\mathrm{BCoVs}$ which makes the infection spread during the warm months.

\section{References}

1-Masters P S (2006). The molecular biology of coronaviruses. Adv. Virus Res. 66: 193-292.
2-Holmes K V, and Lai MM (1996). Coronaviridae: the viruses and their replication: in Fields virology, 
3rd ed. Fields BN, Knipe DM, and Howley PM (ed.) Raven Press, New York, N.Y., pp: 1075-1093.

3-Gay CC, Hodgson JC, Lofstedt J, and Bolin SR (2012). Diarrhea in Neonatal ruminants: intestinal diseases in ruminants: merck veterinary manual.

4-Razzaque MA, Bedair $\mathrm{M}$, Abbas $\mathrm{S}$ and $\mathrm{AL}$ Mutawa T (2009). Economic empact of calf mortality on dairy farms in Kuwait. Pakistan. Vet. J. 29(3):97-101.

5-Leech NL, Barrett K C, and Morgan G A (2011). IBM SPSS For Intermediate statistics. $4^{\text {th }}$ ed. Taylor and Francis Group. LLC.USA.

6-Klein D, Kern A, Lapan G, Benetka V, Möstl K, Hassl A, and Baumgartner W(2009). Evaulation of rapid assays for the detection of bovine coronavirus, rotavirus A and Cryptosporidium parvum in fecal samples of calves. Vet. J.182: 484-486.

7-Al-Kanany KA (2012). Molecular investigation of Bovine Coronavirus in diarrheic calves by using RT-PCR in some governorates of Iraq. MSc thesis in veterinary Medicine-Internal and Preventive Veterinary Medicine. University of Baghdad.

8-Mackay IM (2004). Real-time PCR in the microbiology laboratory. Clin. Microbiol. Infect. 10:190e212.

9-Klein SL (2000). The effects of hormones on sex differences in infection: from genes to behavior. Neurosci. Biobehav. Rev. 24, 627-638.

10-Fish EN (2008). The X-files in immunity: sex-based differences predispose immune responses. Nat. Rev. Immunol. 8: 737-744.

11-Wilson TG, Yerushalmi Y, Donnell DM, and Restifo LL (2006). Interaction between hormonal signaling pathways in Drosophila melanogaster as revealed by genetic interaction between Methoprene-tolerant and Broad-Complex. Genetics. 172(1): 253--264.

12-Hannah MF, Bajic VB, and Klein SL (2008). Sex differences in the recognition of an innate antiviral responses to Seoul virus in Norway rats. Brain. Behav. Immun. 22: 503-516.
13-Hill KE, Pigmans M, Fujinami RS, and Rose JW (1998). Gender variations in early Theiler's virus induced demyelinating disease: differential susceptibility and effects of IL-4, IL-10 and combined IL-4 with IL-10. J. Neuroimmunol. 85: 44-51.

14-Hansa A, Rai RB, Wani MY and Dhama K (2012). ELISA and RT-PCR based detection of bovine coronavirus in Northern India. Asian J. Animal Vet. Adv., 7: 1120-1129.

15-Bidokhti MR, Tråvén $\mathrm{M}$, Krishna NK, Munir M, Belák S, Alenius S and Cortey M (2013). Evolutionary dynamics of bovine coronaviruses: Natural selection pattern of the spike gene implies adaptive evolution of the strains. J. Gen. Virol. 94(Pt 9): 2036-49.

16-Radostits OM, Gay CC, Hinchcliff KW, and Constable PD (2007). Veterinary Medicine, A textbook of the diseases of cattle, horses, sheep, pigs, and goats, 10th edn. SaundersElsevier, Philadelphia, 1286-1296.

17-Saif L J (1990). A review of evidence implicating bovine coronavirus in the etiology of winter dysentery in cows: an enigma resolved? Cornell. Vet. 80(4):303-11.

18-Park SJ, Jeong C, Yoon SS, Choy HE, Saif LJ, Park SH, Kim YJ, Jeong JH, Park SI, Kim HH, Lee, BJ, Cho HS, Kim SK, Kang MI, and Cho KO (2006). Detection and characterization of bovine coronaviruses in fecal specimens of adult cattle with diarrhea during the warmer seasons. J. Clin. Microbiol. 44(9): 3178-88.

19-Martínez A, Caballero M, Silva $S$ and Jiménez C (2002). Aislamiento ycaracterización de coronavirus bovino asociado a un brote de diarrea epizoótica (Disentería Bovina) en bovinos adultos en Costa Rica. III Seminario Internacional de Sanidad Animal y I Seminario de Producción Animal. ESPE, Sangolquí 12-15/11/2002. 